\title{
Pengaruh Kompetensi dan Independensi Terhadap Kinerja Pegawai dengan Komitmen Organisasi sebagai Variabel Intervening
}

\author{
Lutfi Anggraeni' ${ }^{1}$ Irfan Helmy ${ }^{2}$ \\ ${ }^{1}$ Sekolah Tinggi Ilmu Ekonomi Putra Bangsa \\ ${ }^{2}$ Sekolah Tinggi Ilmu Ekonomi Putra Bangsa \\ Email: lutfianggraeni02@gmail.com
}

\section{ARTICLE INFO}

Article History:

Received: March 6th 2020

Accepted: March $7^{\text {th }} 2020$

Published: April 30th 2020

Keywords:

Kompetensi, Independensi, Komitmen Organisasi,

Kinerja Pegawai

\begin{tabular}{l} 
ABSTRACT \\
\hline Penelitian ini bertujuan untuk mengetahui \\
pengaruhKompetensi dan Independensi terhadap Kinerja \\
Pegawai melalui Komitmen Organisasi sebagai variabel \\
intervening. Teknik pengumpulan data yang digunakan \\
adalah dengan menyebarkan kuesioner kepada 43 pegawai \\
PNS Kantor Inspektorat Kabupaten Kebumen. Teknik \\
sampling yang digunakan dalam penelitian ini menggunakan \\
sampel jenuh. Teknik analisis data yang digunakan dalam \\
penelitian ini adalah analisis deskriptif, analisis statistika, \\
analisis jalur, uji hipotesis, analisis korelasi dan uji sobel. \\
Hasil penelitian ini menunjukkan bahwa 1) Kompetensi \\
berpengaruh positif dan signifikan terhadap Komitmen \\
Organisasi, 2) Independensi berpengaruh positif dan \\
signifikan terhadap Komitmen Organisasi, 3) Kompetensi \\
berpengaruh positif dan signifiikan terhadap Kinerja \\
Pegawai, 4) Independensi tidak berpengaruh signifikan \\
terhadap Kinerja Pegawai, 5) Komitmen Organisasi \\
berpengaruh positif dan signifikan terhadap Kinerja Pegawai, \\
6) Komitmen Organisasi mampu memediasi Kompetensi \\
terhadap Kinerja Pegawai, 7) Komitmen Organisasi \\
memperkuat pengaruh Kompetensi dan Kinerja Pegawai. \\
Berdasarkan nilai Adjusted $R$ Square menunjukkan bahwa \\
kontribusi antar variabel pada model pertama sebesar $35 \%$ \\
sisanya sebesar $65 \%$ dipengaruhi oleh variabel lain diluar \\
model dan pada model kedua sebesar $72,2 \%$ sisanya sebesar \\
$27,8 \%$ dipengaruhi oleh variabel diluar model. \\
\hline
\end{tabular}




\section{Pendahuluan}

Sumber daya manusia merupakan sumber dari kekuatan yang berasal dari manusiamanusia yang dapat didayagunakan oleh organisasi (Meldona, 2009). Sumber daya manusia dalam sebuah organisasi merupakan aspek penting untuk menentukan efektif atau tidaknya sebuah organisasi. Sebuah organisasi akan dapat berkembang tergantung pada bagaimana kemampuan pegawainya dalam melaksanakan tugas dan tanggungjawab dalam bekerja.Tinggi rendahnya kinerja yang telah dicapai oleh organisasi dipengaruhi oleh tingkat kinerja pegawai secara individu maupun kelompok.

Kinerja adalah hasil kerja secara kualitas dan kuantitas yang dicapai oleh seorang pegawai dalam melaksanakan tugasnya sesuai dengan tanggung jawab yang diberikan kepadanya. Kinerja pegawai Inspektorat dapat dilihat dari pelaksanaan program kerja yang ditetapkan. Berikut merupakan data Program Kerja Pengawasan Tahunan mulai tahun 2017-2018 :

Tabel 1. Program kerja pengawasan tahunan (pkpt) Inspektorat kab. Kebumen tahun 2017-2018

\begin{tabular}{|c|c|c|c|c|}
\hline \multirow[b]{2}{*}{ Tahun } & \multirow[b]{2}{*}{ Sasaran } & \multirow[b]{2}{*}{$\begin{array}{l}\text { Jumlah } \\
\text { PKPT }\end{array}$} & \multicolumn{2}{|c|}{ Obyek Pemeriksaan } \\
\hline & & & Terlaksana & $\begin{array}{l}\text { Tidak } \\
\text { Terlaksana }\end{array}$ \\
\hline 2017 & $\begin{array}{lr}\text { Desa, Puskesmas, } & \text { SMP, } \\
\text { UPTD } & \text { Dinas } \\
\text { Pendidikan, } & \text { dan } \\
\text { Kecamatan } & \end{array}$ & 56 & 56 & - \\
\hline 2018 & $\begin{array}{l}\text { Desa, Puskesmas, SMP, } \\
\text { UPTD Dinas } \\
\text { Pendidikan, Kecamatan, } \\
\text { Reviu dan pemeriksaan } \\
\text { lainnya. }\end{array}$ & 80 & 80 & - \\
\hline
\end{tabular}

Sumber: Inspektorat Kabupaten Kebumen (2018)

Tabel di atas menunjukkan bahwa tidak ada Program Kerja Pengawasan Tahunan yang tidak terlaksana oleh Inspektorat Kabupaten Kebumen. Pada Tahun 2017 diprogramkan dengan sasaran 56 obrik dan tahun 2018 diprogramkan dengan sasaran 80 obrik. Program tersebut berdasarkan usulan peta risiko yang kemudian dirapatkan hingga menghasilkan kesimpulan yang disebut Program Kerja Pengawasan Tahunan (PKPT). Selain itu, capaian opini Wajar Tanpa Pengecualian (WTP) yang diberikan Badan Pemeriksa Keuangan (BPK) kepada Pemerintah Daerah Kabupaten Kebumen selama lima tahun berturut-turut mulai tahun 2011 terkait Laporan Keuangan Pemerintah Daerah (LKPD) merupakan salah satu bukti bahwa fungsi pengawasan yang dilakukan pegawai Inspektorat Kabupaten Kebumen baik.

Tinggi rendahnya kinerja dapat disebabkan oleh faktor manusia. Salah satu faktor manusia dapat berupa komitmen kepada organisasinya (Wirawan, 2009). Individu yang memiliki komitmen terhadap organisasi cenderung memiliki keterikatan secara psikologis dengan organisasi, sehingga apabila semakin nyaman dan tinggi manfaatnya yang dirasakan oleh anggota maka semakin tinggi komitmen individu pada organisasi.Komitmen pegawai Inspektorat tidak hanya karena adanya status Pegawai Negeri Sipil, namun tercermin dari para pegawai yang bekerja dengan sepenuh hati menyediakan waktu diluar jam kerja misalnya pada saat akhir tahun, mereka dituntut untuk lembur menyelesaikan pekerjaanya. 
Selain itu, proses audit yang memakan waktu cukup lama dengan kondisi dan situasi yang tidak menentu juga menuntut pegawai memiliki komitmen yang tinggi terhadap organisasi. Hal tersebut sudah dilakukan pegawai dengan baik ditandai dengan tidak adanya pegawai yang meninggalkan tanggungjawab individu maupun kelompok dalam pekerjaannya dan dapat diselesaikan sesuai dengan visi misi organisasi.

Selanjutnya Menurut Dale (2003:5) dalam Sudarmanto (2009:48) kompetensi menggambarkan dasar pengetahuan dan standar kinerja yang dipersyaratkan agar berhasil menyelesaikan suatu pekerjaan atau memegang suatu jabatan. untuk meningkatkan kompetensi pegawai salah satunya dengan dilaksanakanya program Pelatihan Kantor Sendiri atau biasa disebut PKS. PKS merupakan kegiatan pelatihan dengan narasumber internal organisasi yang diikuti oleh pegawai dengan jadwal tertentu, selain itu untuk menambah informasi dan pengetahuan baru pegawai lainnya. Selain itu, apabila pegawai telah melaksanakan diklat, pegawai tersebut wajib memaparkan hasil diklat di depan forum guna pembaruan informasi-informasi yang didapat saat diklat. Oleh karena itu, kompetensi sangat dibutuhkan untuk mendukung pelaksanaan pekerjaan pegawai Inspektorat Kabupaten Kebumen.

Selain kompetensi yang memadai, pegawai dituntut untuk memiliki sikap independensi. Independensi berarti sikap mental yang bebas dari pengaruh, tidak dikendalikan pihak lain, tidak tergantung pada orang lain (Mulyadi,2011). Independensi pegawai Inspektorat ditunjukkan dengan penyusunan program kerja yang bebas dari intervensi berbagai pihak dan benar-benar berdasarkan analisis peta lokasi yang telah didiskusikan. Selain itu, pegawai mampu mengesampingkan kepentingan pribadi saat verifikasi dan pelaporan hasil pemeriksaan. Sikap independensi pegawai dibuktikan dengan tidak adanya pegawai yang pernah terlibat dalam kasus. Hal tersebut menunjukkan bahwa independensi pegawai Inspektorat baik.

\section{Kajian Teori dan Telaah Literatur}

\section{Kinerja pegawai}

Kinerja adalah hasil kerja secara kualitas dan kuantitas yang dicapai oleh seorang karyawan dalam melaksanakan tugasnya sesuai dengan tanggung jawab yang diberikan kepadanya (Mangkunegara, 2011). Kinerja adalah tingkat pencapaian hasil atas tugas tertentu (Simanjuntak, 2011). Mathis dan Jackson (2006) menyatakan bahwa kinerja (performance) pada dasarnya adalah apa yang dilakukan atau tidak dilakukan oleh karyawan. Berdasarkan beberapa pengertian yang telah diuraikan, dapat disimpulkan bahwa kinerja pegawai merupakan hasil dari suatu proses atau aktivitas pada fungsi tertentu yang dilaksanakan pegawai. Hasil tersebut merupakan tingkatan dimana pegawai menyelesaikan pekerjaan sesuai dengan syarat-syarat yang telah ditentukan.

\section{Komitmen organisasi}

Komitmen organisasi adalah suatu keadaan dimana seorang karyawan memihak organisasi tertentu serta tujuan-tujuan dan keinginannya untuk mempertahankan keanggotaan dalam organisasi tersebut. Jadi keterlibatan pekerjaan yang tinggi berarti memihak pada pekerjaan tertentu seorang individu, sementara komitmen organisasional yang tinggi berarti memihak 
organisasi yang merekrut individu tersebut (Robbins, 2008). Sedangkan menurut Luthan (2006) komitmen organisasi adalah keinginan kuat untuk tetap sebagai anggota organisasi tertentu, keinginan untuk berusaha keras sesuai dengan keinginan organisasi, serta keyakinan tertentu dan penerimaan nilai dan tujuan organisasi. Dengan kata lain merupakan sikap yang merefleksikan loyalitas karyawan pada organisasi dan proses berkelanjutan dimana anggota organisasi mengekspresikan perhatiannya terhadap organisasi dan keberhasilan serta kemajuan yang berkelanjutan.

\section{Kompetensi}

Menurut Wibowo (2016:271) mengemukakan bahwa kompetensi adalah suatu kemampuan untuk melaksanakan atau melakukan suatu pekerjaan atau tugas yang dilandasi atas keterampilan dan pengetahuan serta didukung oleh sikap kerja yang dituntut oleh pekerjaan tersebut. Keterampilan atau kemampuan yang diperlukan pegawai yang ditunjukkan oleh kemampuan dengan konsisten memberikan tingkat kinerja yang memadai atau tinggi dalam suatu fungsi pekerjaan. Kompetensi merupakan penguasaan terhadap tugas, keterampilan, sikap, dan apresiasi yang diperlukan untuk menunjang keberhasilan. Sedangkan menurut Wibowo (2014:271) kompetensi adalah suatu kemampuan untuk melaksanakan atau melakukan suatu pekerjaan atau tugas yang dilandasi atas keterampilan dan pengetahuan serta didukung oleh sikap kerja yang dituntut oleh pekerjaan tersebut.Berdasarkan pengertian tersebut di atas dapat disimpulkan bahwa kompetensi merupakan karakteristik yang melekat pada diri seseorang yang menyebabkan seseorang itu akan mampu untuk memprediksi sekelilingnya dalam suatu pekerjaan atau situasi.

\section{Independensi}

Independensi merupakan terjemahan kata independence yang berasal dari Bahasa Inggris, yang artinya "dalam keadaan independen", adapun arti kata independen bermakna "tidak tergantung atau dikendalikan oleh (orang lain atau benda), tidak mendasarkan pada diri pada orang lain, bertindak atau berpikir sesuai dengan kehendak hati, bebas dari pengendalian orang lain, tidak dipengaruhi oleh orang lain.Menurut Arens et al (2008:111), independensi dalam audit berarti mengambil sudut pandang yang tidak bias. Independensi sangat penting bagi auditor untuk dijaga dalam melaksanakan tanggung jawabnya. Menurut Halim (2008:46), independensi merupakan suatu cerminan sikap dari seorang auditor untuk tidak memilih pihak siapapun dalam melakukan audit.Berdasarkan penjelasan di atas, maka Independensi auditor pemerintah adalah sikap tidak memihak kepada kepentingan siapa pun dalam melakukan pemeriksaan laporan keuangan yang dibuat oleh pihak manajemen. Auditor pemerintah berkewajiban untuk jujur tidak hanya kepada pemerintah, namun juga kepada lembaga perwakilan dan pihak lain yang meletakkan kepercayaan atas pekerjaan auditor pemerintah. 


\section{Model Penelitian}

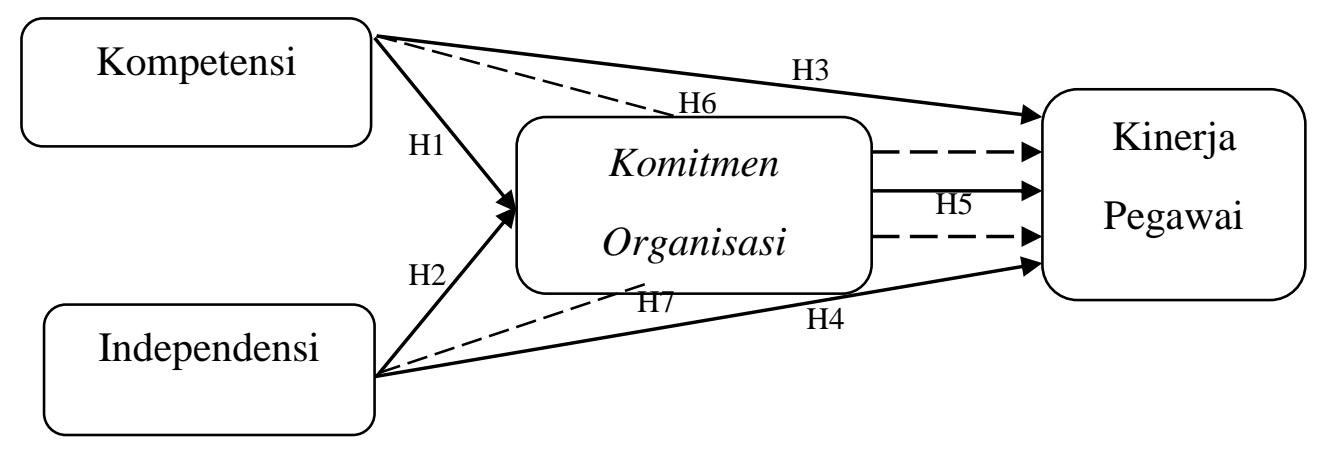

Gambar 1. Model penelitian

\section{Metode Penelitian}

\section{Sampel dan data}

Metode yang digunakan dalam penelitian ini adalah metode kuantitatif. Populasi dalam penelitian ini yaitu pegawai PNS Kantor Inspektorat Kabupaten Kebumen sejumlah 43 orang. Pengambilan sampel dalam penelitian ini adalah dengan menggunakan teknik sensus. Metode ini mengisyaratkan semua anggota populasi disampel penelitian, karena terbatasnya jumlah sampel. Maka dalam penelitian ini sampel adalah keseluruhan populasi yang berjumlah 43 responden.Sumber data yang digunakan dalam penelitian adalah data primer dan sekunder. Data primer diperoleh dari hasil penyebaran kuesioner dan data kepegawaian, sedangkan data sekunder diperoleh dari jurnal, penelitian terdahulu, artikel, buku. Teknik pengumpulan data dalam penelitian ini menggunakan kuesioner, study pustaka dan wawancara.

\section{Pengukuran variabel}

Pengukuran kinerja pegawai menurut Fadel (2009:195) sebagai berikut: 1) pemahaman atas tupoksi, 2) memiliki inovasi, 3) kecepatan kerja, 4) keakuratan kerja, 5) kerjasama.Pengukuran Komitmen Organisasi menurut Mowday, Portter dan Steers (1982) sebagai berikut : 1) kepercayaan yang kuat terhadap nilai serta tujuan organisasi, 2) keinginan untuk memberikan usaha terbaik terhadap organisasi, 3) hasrat yang kuat untuk mempertahanlkan keanggotaan dalam organisasi.Pengukuran kompetensi menurut Gordon dalam Sutrisno (2011:204) sebagai berikut: 1) Pengetahuan (knowledge), 2) pemahaman (understanding), 3) kemampuan/keterampilan (skill), 4) nilai (value),5) sikap (attitude), 6) minat (interest).Pengukuran independensi menurut Mulyadi (2008) sebagai berikut: 1) sikap mental bebas dari pengaruh, 2) tidakdikendalikan pihak lain, 3) tidak tergantung pada orang lain.

\section{Hasil dan Pembahasan}

Penelitian ini menggunakan analisis jalur (path analysis) merupakan suatu teknik analisis statistika yang dikembangkan dari analisis regresi berganda. Analisis data dilakukan dengan menggunakan program SPSS versi 23,0. Metode atau teknik penelitian dalam penelitian ini adalah: 
Tabel 2. Ringkasan uji validitas dan reliabilitas

\begin{tabular}{lllc}
\hline No & \multicolumn{1}{c}{ Variabel } & $($ Sig. <0,05) & $\begin{array}{c}\text { Keterangan } \\
\text { Reliabilitas } \\
(\text { Cronbach Alpha }>0,70)\end{array}$ \\
\hline 1. & Kompetensi & Valid & 0,844 \\
2. & Independensi & Valid & 0,805 \\
3. & Komitmen Organisasi & Valid & 0,830 \\
4. & Kinerja Pegawai & Valid & 0,846 \\
\hline
\end{tabular}

Sumber: Data diolah (2019)

Uji normalitas dilakukan dengan uji statistik P-Plot yang hasilnya menunjukkan bahwa data menyebar di sekitar garis diagonal dan mengikuti arah garis diagonal, maka model regresi tersebut memenuhi asumsi normalitas. Hasil uji multikolinearitas menunjukkan bahwa semua nilai tolerance $>0,10$ dan untuk nilai VIF $<10$. Hal ini berarti bahwa tidak terjadi multikolinearitas dalam model regresi. Selanjutnya berdasarkan hasil output scatterplot dalam penelitian ini menunjukkan bahwa tidak terdapat pola yang jelas, serta titik-titik pada grafik menyebar diatas dan dibawah angka 0 (nol) pada sumbu $\mathrm{Y}$, maka tidak terjadi heteroskedastisitas sehingga model regresi tersebut dapat dipakai.

Tabel 3. Hasil uji parsial (uji t) struktural 1

\begin{tabular}{|c|c|c|c|c|c|c|}
\hline \multicolumn{7}{|c|}{ Coefficients ${ }^{a}$} \\
\hline & & \multicolumn{2}{|c|}{$\begin{array}{l}\text { Unstandardized } \\
\text { Coefficients }\end{array}$} & \multirow{2}{*}{$\begin{array}{c}\text { Standardized } \\
\text { Coefficients } \\
\text { Beta }\end{array}$} & \multirow[b]{2}{*}{$\mathrm{T}$} & \multirow[b]{2}{*}{ Sig. } \\
\hline \multicolumn{2}{|c|}{ Model } & $\mathrm{B}$ & Std. Error & & & \\
\hline \multirow[t]{3}{*}{1} & (Constant) & 5.371 & 2.653 & & 2.025 & .050 \\
\hline & Kompetensi & .263 & .120 & .320 & 2.196 & .034 \\
\hline & Independensi & .347 & .130 & .387 & 2.659 & .011 \\
\hline & pendent Variab & itmen & Drganisasi & & & \\
\hline
\end{tabular}

Tabel 4. Hasil uji parsial (uji t) struktural 2

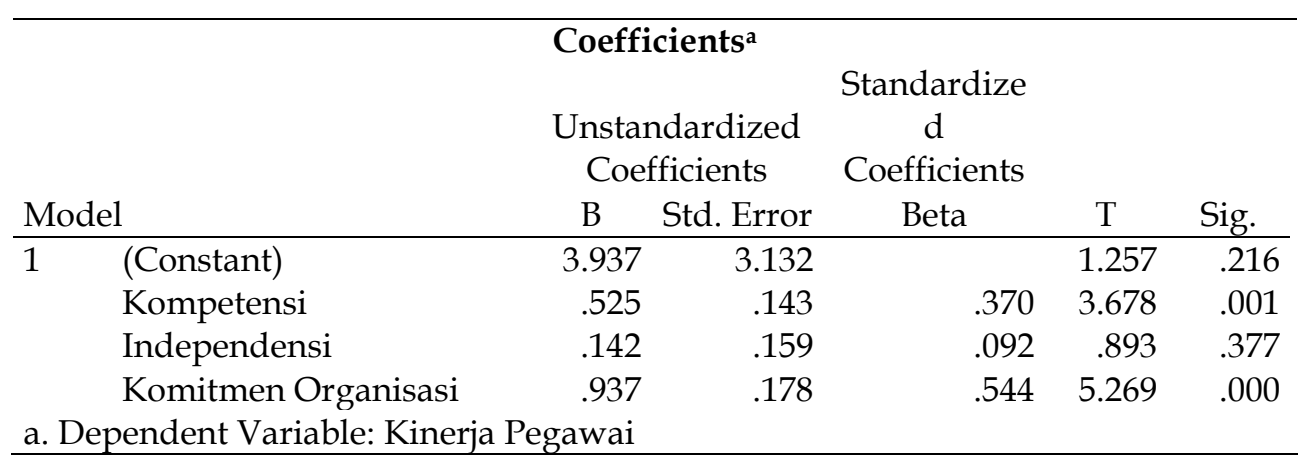




\section{Pengaruh kompetensi terhadap komitmen organisasi}

Berdasarkan uji t substruktural I pada tabel 2, menunjukan bahwa probabilitas signifikansi untuk variabel Kompetensi $\left(\mathrm{X}_{1}\right)$ sebesar 0,034<0,05 dan perhitungan diperoleh angka $t_{\text {hitung }}$ sebesar 2,196 $>t_{\text {tabel }}$ 2,020 sehingga $\mathrm{H}_{0}$ ditolak dan $\mathrm{H}_{1}$ diterima. Pengaruh Kompetensi yang positif dan signifikan terhadap Komitmen Organisasi mengidentifikasikan bahwa Kompetensi yang dimiliki pegawai Inspektorat Kabupaten Kebumen memadai, apabila dilihat dari latar belakang pendidikan pegawai yang meliputi sarjana akuntansi, sarjana manajemen, sarjana ilmu pemerintahan, sarjana ilmu teknik, dan sarjana ilmu hukum. Dengan adanya pengetahuan dan keterampilan yang memadai, pegawai dapat memahami tugas dan fungsinya dalam organisasi sehingga dapat bekerja secara efisien, efektif sesuai dengan aturan yang ditetapkan oleh organisasi.

\section{Pengaruh independensi terhadap komitmen organisasi}

Sedangkan untuk variabel Independensi $\left(\mathrm{X}_{2}\right)$ sebesar 0,011<0,05 dan perhitungan diperoleh angka $t_{\text {hitung }}$ sebesar 2,659 $>t_{\text {tabel }} 2,020$ sehingga $\mathrm{H}_{0}$ ditolak sedangkan $\mathrm{H}_{1}$ diterima. Independensi mencerminkan sikap tidak memihak terhadap siapapun, tidak bertentangan, tidak dapat dikendalikan oleh orang lain. Seorang auditor yang memiliki komitmen terhadap organisasi tentunya akan berusaha mewujudkan tujuan organisasi salah satu cara yang dilakukan adalah dengan menjunjung tinggi sikap independensi sehingga dalam memberikan opini atas kewajaran laporan keuangan sesuai dengan pedoman organisasi untuk menjaga tingkat independensi agar tetap sesuai dengan jalur yang seharusnya.

\section{Pengaruh kompetensi terhadap kinerja pegawai}

Berdasarkan uji t substruktural II pada tabel 3, menunjukan bahwa probabilitas signifikansi untuk variabel Kompetensi $\left(X_{1}\right)$ sebesar 0,001 $<0,05$ dan perhitungan diperoleh angka $t_{\text {hitung }}$ sebesar 3,678 $>t_{\text {tabel }} 2,021$ sehingga $\mathrm{H}_{0}$ ditolak sedangkan $\mathrm{H}_{1}$ diterima. Kompetensi sangat berperan penting dalam mendorong secara positif kinerja pegawai Inspektorat Kabupaten Kebumen. Semakin tinggi kompetensi yang dimiliki oleh pegawai dengan dukungan kegiatan pelatihan seperti Pelatihan Kantor Sendiri (PKS), Pendidikan dan Pelatihan yang berkelanjutan hingga bimbingan teknis yang rutin dilaksanakan diharapkan dapat menunjang pelaksanaan pekerjaan dan berimbas terhadap kinerja pegawai.

\section{Pengaruh independensi terhadap kinerja pegawai}

Untuk variabel Independensi $\left(X_{2}\right)$ sebesar $0,377>0,05$ dan perhitungan diperoleh angka $t_{\text {hitung }}$ sebesar $0,893<t_{\text {tabel }}$ sebesar 2,021 $(0,893<2,021)$ sehingga $\mathrm{H}_{0}$ diterima sedangkan $\mathrm{H}_{1}$ ditolak. Independensi tidak memiliki pengaruh signifikan terhadap kinerja pegawai. Hasil ini mengidentifikasikan bahwa tinggi rendahnya tingkat independensi di Kantor Inspektorat Kabupaten Kebumen tidak berdampak signifikan terhadap capaian kerja pegawai. Sikap indepedensi merupakan sikap dasar yang sudah tertanam dalam diri seorang auditor bahkan sudah ada sebelum auditor tersebut melaksanakan tugasnya. Akan tetapi, pelaksanaan tugas yang terstruktur menjadikan pegawai bekerja sesuai prosedural dengan berpedoman kode etik sehingga menjadikan pegawai bekerja secara administratif dan transparan. Hal ini menjadi alasan independensi tidak berdampak signifikan terhadap kinerja.

\section{Pengaruh komitmen organisasi terhadap kinerja pegawai}


Untuk variabel komitmen organisasi $\left(\mathrm{Y}_{1}\right)$ sebesar $0,000<0,05$ dan perhitungan diperoleh

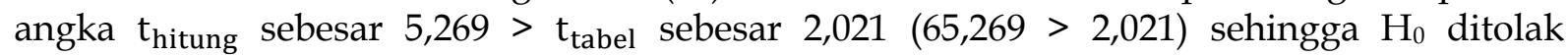
sedangkan $\mathrm{H}_{1}$ diterima. Dengan adanya komitmen dapat menjadi dorongan bagi pegawai untuk dapat bekerja secara maksimal. Pengaruh komitmen organisasi terhadap kinerja mengidentifikasikan bahwa pegawai Kantor Inspektorat Kabupaten Kebumen memiliki komitmen terhadap organisasi dengan membantu mewujudkan tujuan organisasi dan loyalitas untuk tetap menjadi anggota organisasi. Hal tersebut menjadikan para pegawai merasa terikat dengan nilai-nilai organisasional yang ada sehingga dalam melakukan pekerjaan para pegawai merasa senang dan kinerjanya dapat meningkat.

\section{Pengaruh kompetensi terhadap kinerja pegawai melalui komitmen organisasi}

Berdasarkan uji parsial, Kompetensi $\left(\mathrm{X}_{1}\right)$ memiliki pengaruh langsung terhadap Kinerja Pegawai $\left(\mathrm{Y}_{2}\right)$ sebesar 0,370 sedangkan ketika melalui Komitmen Organisasi $\left(\mathrm{Y}_{1}\right)$ memiliki pegaruh tidak langsung sebesar 0,17408 dan pengaruh total sebesar 0,846. Hal tersebut dapat diartikan bahwa dalam penelitian ini terdapat pengaruh partial mediation. Didukung oleh hasil uji sobel menggunakan calculator sobel test online, penelitian ini menunjukkan nilai $p$ value sebesar 0,04304152 yang kurang dari nilai signifikansi yaitu 0,05 sehingga dapat diartikan bahwa komitmen organisasi berpengaruh secara signifikan terhadap kompetensi dan kinerja pegawai atau dapat disimpulkan bahwa komitmen organisasi dapat memediasi hubungan kompetensi dengan kinerja pegawai.

\section{Pengaruh independensi terhadap kinerja pegawai melalui komitmen organisasi}

Didukung oleh hasil uji sobel menggunakan calculator sobel test online, penelitian ini menunjukkan nilai p-value sebesar 0,04379986 yang kurang dari nilai signifikansi yaitu 0,05 sehingga dapat diartikan bahwa komitmen organisasi berpengaruh secara signifikan terhadap independensi dan kinerja pegawai atau dapat disimpulkan bahwa komitmen organisasi dapat memediasi hubungan independensi dengan kinerja pegawai. Komitmen organisasi pegawai ditunjukkan dengan loyalitas pegawai melaksanakan tugas dan fungsinya untuk mencapai target yang ingin dicapai organisasi, untuk mencapai hal tersebut dibutuhkan sikap independensi pegawai terkait transparansi administrasi dan pelaporan. Dengan adanya komitmen terhadap organisasi dan sikap independensi pegawai maka akan berdampak signifikan terhadap capaian kinerja pegawai.

Koefisien determinasi menunjukan besarnya kontribusi variabel bebas terhadap variabel terikat.

Tabel 5. Hasil output koefisien determinasi struktural 1

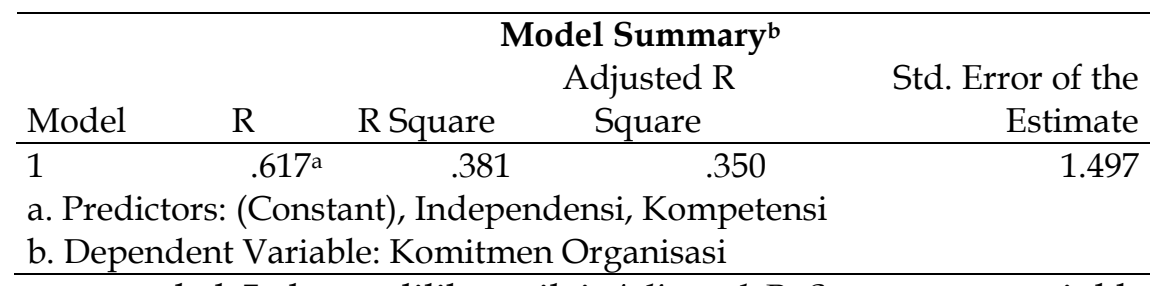

Berdasarkan output tabel 5 dapat dilihat nilai Adjusted $R$ Square menunjukkan nilai 0,350 atau dapat diartikan sebesar $35 \%$ Komitmen Organisasi $\left(\mathrm{Y}_{1}\right)$ Inspektorat Kabupaten Kebumen dipengaruhi oleh kompetensi $\left(X_{1}\right)$ dan independensi $\left(X_{2}\right)$, sedangkan sisanya dipengaruhi oleh variabel lain. 
Tabel 6. Hasil output koefisien determinasi struktural 2

\begin{tabular}{|c|c|c|c|c|}
\hline \multicolumn{5}{|c|}{ Model Summary } \\
\hline & & & Adjusted R & \multirow{2}{*}{$\begin{array}{l}\text { Std. Error of the } \\
\text { Estimate }\end{array}$} \\
\hline Model & $\mathrm{R}$ & R Square & & \\
\hline 1 & $.862^{\mathrm{a}}$ & .742 & .722 & 1.683 \\
\hline \multicolumn{5}{|c|}{$\begin{array}{l}\text { a. Predictors: (Constant), Komitmen Organisasi, Kompetensi, } \\
\text { Independensi } \\
\text { b. Dependent Variable: Kinerja Pegawai }\end{array}$} \\
\hline
\end{tabular}

Berdasarkan output di atas dapat dilihat nilai koefisien determinasi Adjusted $R$ Square diperoleh 0,722 atau dapat diartikan sebesar 72,20 \% Kinerja Pegawai Inspektorat Kabupaten Kebumen dipengaruhi oleh variabel kompetensi $\left(X_{1}\right)$, independensi $\left(X_{2}\right)$ dan komitmen organisasi $\left(\mathrm{Y}_{1}\right)$, sedangkan sisanya dipengaruhi oleh variabel lain yang tidak ada dalam penelitian ini.

\section{Penutup dan Saran}

\section{Simpulan}

Hasil penelitian ini menunjukkan bahwa Kompetensi berpengaruh positif dan signifikan terhadap Komitmen Organisasi, Independensi berpengaruh positif dan signifikan terhadap Komitmen Organisasi, Kompetensi berpengaruh positif dan signifiikan terhadap Kinerja Pegawai, Independensi tidak berpengaruh signifikan terhadap Kinerja Pegawai, Komitmen Organisasi berpengaruh positif dan signifikan terhadap Kinerja Pegawai, Komitmen Organisasi mampu memediasi Kompetensi terhadap Kinerja Pegawai, Komitmen Organisasi memperkuat pengaruh Kompetensi dan Kinerja Pegawai.

\section{Keterbatasan}

a. Penelitian ini belum dapat mengungkapkan secara keseluruhan faktor yang mempengaruhi Kinerja Pegawai di Kantor Inspektorat Kabupaten Kebumen, penelitian ini hanya terbatas pada faktor Kompetensi, Independensi dan Komitmen Organisasi.

b. Penelitian ini melibatkan subjek yang sangat terbatas, yaitu Kantor Inspektorat Kabupaten Kebumen dengan populasi dan sampel seluruh pegawai PNS Inspektorat Kabupaten Kebumen.

c. Adanya keterbatasan penelitian dengan menggunakan kuesioner yaitu terkadang jawaban yang diberikan oleh responden tidak menunjukkan keadaan yang sesungguhnya. 


\section{Referensi}

Armstrong, M. (2005). Manajemen Sumber Daya Manusia. Jakarta: PT Elexmedia Komputindo.

Edy, S. (2011). Manajemen Sumber Daya Manusia. Jakarta: Penerbit Kencana.

Ghorbanpour, Z., Dehnavi, H. D., \& Heyrani, F. (2014). Investigating the effect of organization commitment on performance of auditors in the community of certified accountants. Interdisciplinary Journal of Contemporary Research in Business, 5(10), 199-209.

Ghozali, I. (2011). Aplikasi Analisis Multivariate Dengan Program SPSS. Semarang: Badan Penerbit Universitas Diponegoro.

Istiariani, I. (2018). Pengaruh Independensi, Profesionalisme, dan Kompetensi Terhadap Kinerja Auditor BPKP (Studi Kasus pada Auditor BPKP Jateng). Islamadina: Jurnal Pemikiran Islam, 19(1), 63-88.

Lotunani, A., Idrus, M. S., Afnan, E., \& Setiawan, M. (2014). The effect of competence on commitment, performance and satisfaction with reward as a moderating variable (A study on designing work plans in Kendari City Government, Southeast Sulawesi). International Journal of Business and Management Invention, 3(2), 18-25.

Qamariah, I., \& Fadli. (2011). Pengaruh Perencanaan Dan Kompetensi Karyawan Terhadap Kinerja Karyawan Pada Pt. Indonesia Asahan Alumunium Kuala Tanjung. Jurnal Ekonomi, 14(2).

Safitri, D. (2014). Pengaruh independensi auditor dan gaya kepemimpinan terhadap kinerja auditor dengan komitmen organisasi sebagai variabel intervening. Jurnal Ilmiah Ekonomi dan Bisnis Unilak, 11(2), 96634.

Setiadi, A., Winarti, E., \& Taufiq, M. (2016). Analisis Komunikasi dan Kompetensi Terhadap Komitmen Organisasi dengan Pengembangan Karir sebagai Vaiabel Moderasi (Studi Kasus Pada Akademi Kepolisian Semarang). Dharma Ekonomi, 23(44).

Sujana, E. (2012). Pengaruh kompetensi, motivasi, kesesuaian peran dan komitmen organisasi terhadap kinerja auditor internal Inspektorat Pemerintah Kabupaten (Studi pada Kantor Inspektorat Kabupaten Badung dan Buleleng). Jurnal Ilmiah Akuntansi dan Humanika, 2(1).

Wibowo. (2009). Manajemen Kinerja. Jakarta: PT. Raja Grafindo Persada.

Yamali, F. R. (2017). Pengaruh kompensasi dan kompetensi terhadap komitmen organisasi serta implikasinya pada kinerja tenaga ahli perusahaan jasa konstruksi di provinsi jambi. Ekonomis: Journal of Economics and Business, 1(1), 213-222. 